\title{
立体視のできる電子顕微鏡下のマイクロ マニュピレーション
}

\author{
畑 村 洋 太 郎*
}

\section{1. ナノメータの世界之, 人間の世界を結ぶ}

人間が通常の世界にいながらにしてナノィータの世界 で物をいじくれたらどんなにすばらしいことかと考え, 筆者らはその夢の実現に努力している．人間が作業を行 らために, 配置・形状・カなどが通常の世界にいるのと 同程度の大きさで感じられることと，逆に人間がやりた いこと・やろらとすることが，超微細な世界に伝達され， 実行されることが必要である. 図 1 は加工の分野におい て, 通常の大きさの世界とナノメータオーダの世界とを 結び付けるために必要な機能を示したものである.

人間が五感を用いて行っている作業のうち最も基本的 な要素は, 両目による立体視, 左手による物の把持, 右 手による加工，の3つの機能であり，それらを超微細な 動きとして実現することがその基本である．このように 考えると左右の 2 方向から見た像を払大し左右の目に伝 える立体視払大装置, 物を把持して超微細な位置ぎめが できるとともに加工によって生じる微小な力を検出して 払大する装置, 工具を持って同じく位置ぎめと力の検出 のできる装置, の 3 つの基本構成装置を持ち, さらに超 微細な世界と人間の通常の世界とを結びつける払大・縮 小・制御のシステムが基本構成をなすことが分かる. 筆 者らはこのような基本機能と構成を持つシステムを“ナ ノロボットシステム”と名付けた。 このようなシステム

原稿受付 1990 年 6 月 11 日

Micromanipulation through Stereoscopic Microscope

* 東京大学工学部

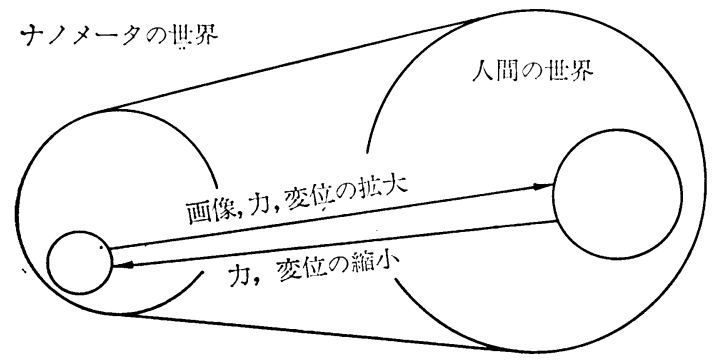

図 1 ナノメーターの世界と人間の世界とを結び付 ける手段
によれば，人は通常の大きさの世界にいながら，自らの 体が縮み，あたかもナノメータオーダの世界の中にいる かのような感覚で超微細な加工を行うことができる.

\section{2. ナノロボットの基本構成}

現在筆者らが開発中のナノロボットシステムの一例を 図 2 に示す ${ }^{1,2)}$.

双眼 SEM の真空チャンバ内に右手ロボットと左手口 ボットがある. 左手ロボットは 6 軸微動テーブルと 2 軸 のテーブル粗動機構とからなる. 加工材は 6 軸微動テー ブルの上にセットする.テーブル粗動機構は 6 軸微動テ ーブル全体の位置を動かすことによって加工位置を双眼 SEM の視野に収める役割を持つ.

右手ロボットは 3 軸ナノロボットとその 3 軸粗動機構 とからなる. 3 軸粗動機構は工具等の“エンドイフェク タ”の先端を加工位置の近くに移動し, 加工位置が 3 軸 ナノロボットが届く範囲内にくるようにする役割を持つ。

工具と 3 軸ナノロボットとの間に高感度の小さな 6 軸 カセンサがあり, 工具と試料との接点に作用する微細な 力の大きさと方向を検出する.

操作者は右の制御レバーによって 3 軸ナノロボットと その粗動機構を操作し, 左の制御レバーによって 6 軸微 動テーブルを操作する. カセンサと微動機構が制御レバ 一内に取り付けられており, 真空チャンバ内の力七ンサ の情報から対応した力（扗大された力）を発生させ, ナ ノロボットの対応した動き（拡大された動き）を発生さ せる. 一方, 反対に制御レバーの操作から生じた力と变 位は一定の割合で縮小され，真空のチ+ンバ内のナノロ ボットに伝達される.

このナノロボットシステムを用いれば，操作者は約 $10 \mu \mathrm{m}$ ほどの超微細な対象を $0.01 \mu \mathrm{m}$ の精度で, しか も対象が 1 万倍に拡大され机の上に置かれているかのよ らな感覚で容易に扱うことが可能になる.

操作位㯰の立体像を実時間で得るための双眼 SEM の 動作原理を図 3 に示す. 走査電子ビームは時分割操作に よって2つに分けられ，左右の視線にそれぞれ対応する 2 方向から加工位固に照射され，2つの映像をそれぞれ 


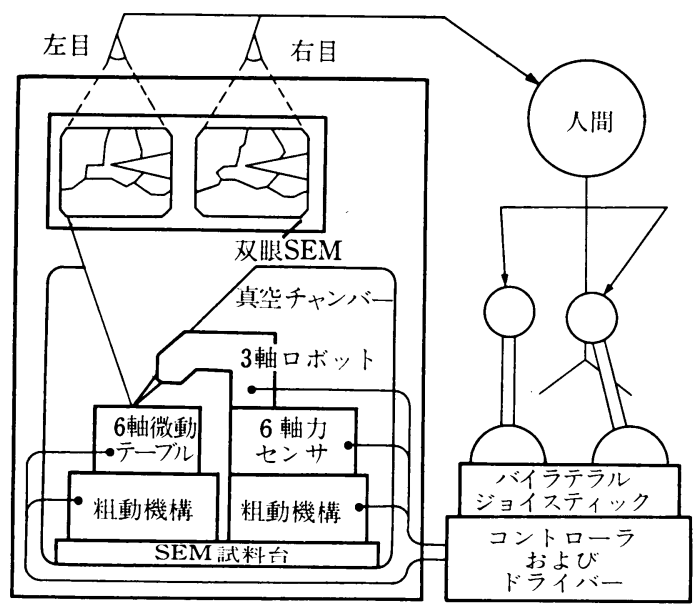

図 2 ナノロボットシステムの一例

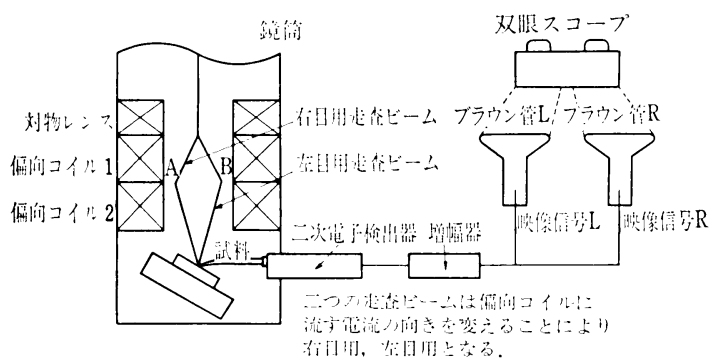

図 3 立体走查形電子顕微鏡の基本構成

左右の CRT 画面に映し出す.

力の検出に用いる平行平板構造を図 4（a）に示す. 固定部之可動部が上下 2 枚の薄板（平行合板）で結び付 けられ，それぞれの根元の表面 4 力所にひずみゲージが 貼付けられている. 平行平板の表面に垂直な方向の力を 受けると同図（b) に示寸よらに変形し，ひずみゲージ は伸縮するのでそれらをブリッジに組めば力が電圧の変 化として検出される.

微動機構としては図 5（a）に示す平行平板構造と压 電素子の組合せ構造が用いられる. 平行平板に挾まれた 空間に固定部と可動部からそれぞれ柱を突き出させ $2 つ$ の柱の間に積層形王電アクチュエータを搟入する. アク チュエータと柱は特殊な接着剤で接着されている. 压電 素子に電圧を加えると同図（b）に示すように可動部が 水平方向に移動するが，その移動量を平行平板に貼付け たひずみゲージで検出する。このような構造を用いれば， 予めレーザー干渉計などを用いて精密な検定を行ってお けば，以降は変位信号は精度よくひずみゲージ出力で得 られるので，多段に重ねて多自由度の微動機構を作った 場合, その位置や姿勢の情報が外部からの测定によらず 内部情報として得ることができる. 压電アクチュエータ にかける電圧を制御し、ひずみゲージの出力をつィード

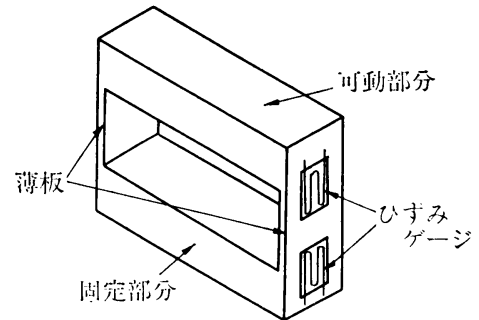

(a) 㤔说

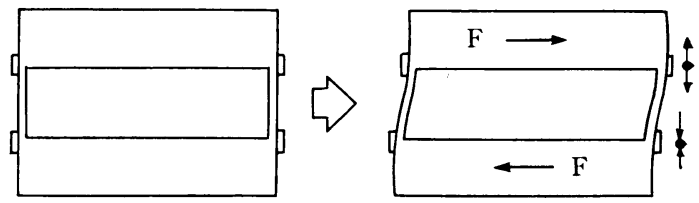

(b) 変形

図 4 平行平板構造とその变形

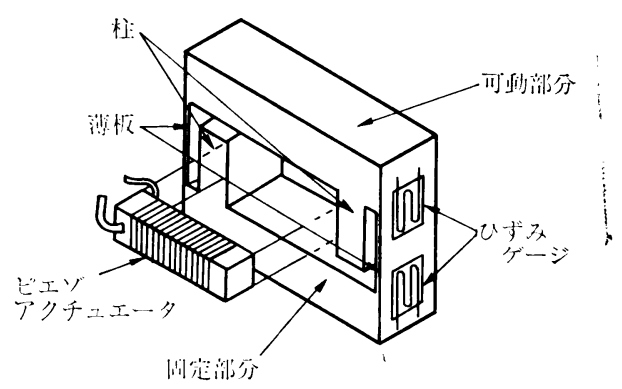

(a) 临隹

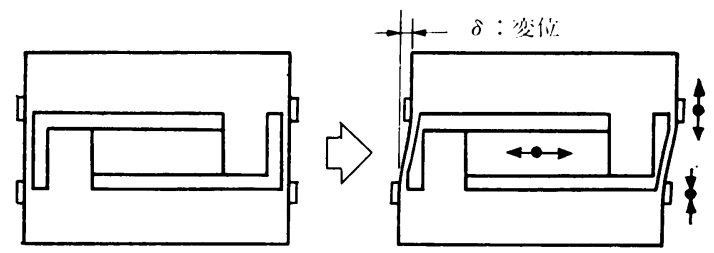

(b) 炃形

图 5 ナノメーター変位の発生機構とその変形 バック量として用いることにより，可動部の変位に対す る圧電アクチュエータの履歴性の影響を無視することが できる

\section{3. ナノロボット実現のための具体的試み}

筆者らはナノロボットシステムのプロトタイプを考案 し，それを用いてアルミニウム材を超微細加工すること に成功し，このシステムが大いに有用であることを確認 した2!

このプロトタイプのシステムには双眼 SEM， 3 軸口 ボットのプロトタイプ, 高感度の単軸力七ンサ, 工具と 


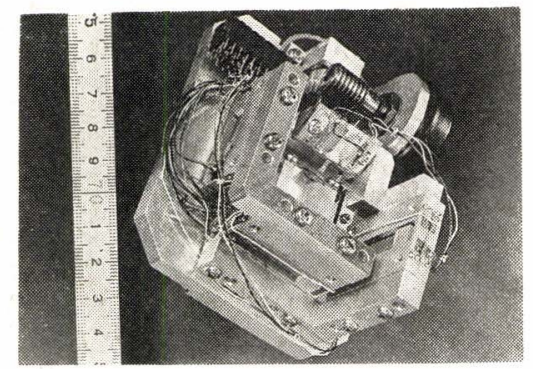

写真 1 試作したナノロボットシステムの外観

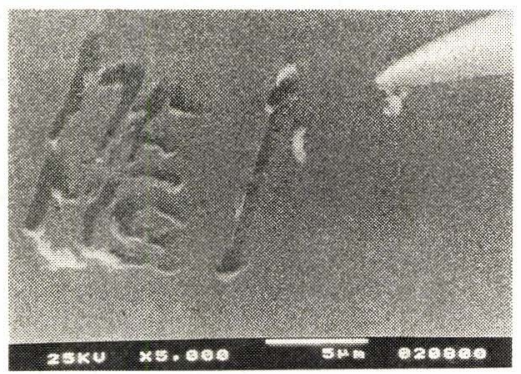

写真 2 ナノロボットシステムでアルミニウム板に 彫り込んだ文字 (MEMS) の例

しての鋭い針, 水平方向の 1 軸に動く（6軸微動テーブ ルの代用）試料台が取り大れられている，写真 1 は 3 軸 ナノロボットの外観と双眼 SEM の真空チャンバ内にあ る試料台である. 試料台は試料を水平上の 1 軸慟かす ことができる、試料台を動かすために超音波モーターが 使われている.この試料台は 6 軸微動テーブルと粗動機 構の代用で, 真空チャンバ内のベース板の上に置かれて いる.

3 つの微動機構からなる 3 軸ナノロボットも試料台を 取り囲むように同じべース板の上に置かれている．３軸 ナノロボットの X 軸, Y 軸, Z 軸上の最大ストロークは $12.5 \mu \mathrm{m}$ で, 最小分解能は $0.01 \mu \mathrm{m}$ である.

3 軸ナ, ロボットの上部には高感度の 1 軸力センサが 取り付けられている. このカセンサの定格値は $0.5 \mathrm{~N}$ で $8000 \mu \mathrm{st} / \mathrm{N}$ の感度である. 固有振動数は $1.5 \mathrm{kHz}$ で, 取り付けられている鋭い針はタングステン製で先端の半 径は約 $0.1 \mu \mathrm{m}$ である.

このプロトタイプのシステムを使ってアルミニウムの 板に小さな引っかき傷をつけるといら単純な実験を行っ た. その結果を写真 2 に示す. 約 $10 \mu \mathrm{m}$ 角の範囲に MEMS の4文字が彫り込まれていることが分かる，な お溝の深さは $0.27 \mu \mathrm{m}$, 幅約 $1 \mu \mathrm{m}$ となっている.この 実験で，傷をつける力は $3.25 \times 10^{-4} \mathrm{~N}$ と測定された。 ここで，傷の深さはカセンサの弾性変形からロボットの
変位を差し引くことによって算定される.

何度か実験を繰り返した後, 双眼で見ることができ， カのフィードバック量を調製できるこのシステムはこの ような機械加工には非常に有用であり, 設計概念は正し いものであることが分かった。

\section{4. 将 来の展 望}

筆者らは加工の経験を通じて, 人間が通常の大きさの 世界にいるの之同様の感覚でナノメータオーダの世界に おいて加工を行うことを可能にするシステムとして，ナ ノロボットシステムを考案した．将来ナノロボットシス テムが完成するば，多くの分野で用いられるようになる だろう，材料試験の分野では，極薄膜フィルムや極鳜細 部の異質な構造の機械的性質を記述することが可能にな るであろう。精密機械の分野では, 精密機械の組み立て, 試験, 調整などの手段として用いることが可能である.

また，対象の表面の正確な様子を分子レベルで観察する FFM, AFM, STM としても用いられよう.さらにナ, ロボットシステムによって, 表面の形状と状態を記憶二 ニットとして用いた全く新しい高密度の情報記憶装置を 製作することも可能になると考えられる.

ナノロボットシステムは必ずやわれわれの眼前にナ, メータオーダの世界への道を開いてくれると期待される.

研究に助言をしてくださった日立建機(株)の小野耕三 氏ならびに双眼 SEM に関して快く協力してくださった サンユー電子(株)の後藤勝人氏に感謝の意を表したい.

参考 文 献

1）畑村洋太郎, “超微細 3 次元加エシステム”, 日本機械学 会ワークショップ“機械工学にお吅る分子工学”テキス 卜, 1989-4.

2) Yotaro HATAMURA and Hiroshi MORISHITA, "Direct Coupling System between Nanometer World and Human World", Micro Electro Mechanical Systems (Napa Valley, California), 203-208, 1990 -2 .

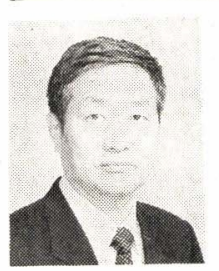

\section{畑村洋太郎}

(Yotaro HATAMURA)

1941年 1 月生まれ, 1964年東京大学工学 部卒業, 1983年東京大学教授

加工の研究 :ナノロボットシステムの開

発, 超精密切削の知能化の研究,

情報機器の基礎研究 : 磁気ディスクヘッ ドのクラッシニ防止の研究, 積層基板の圧着の研究, カセンサ とその応用の研究

日本機械学会, 精密工学会, プリント回路学会会員

現在 東京大学教授工学部産業機械工学科 